on the high tundra plateaux on our ponies. Then we tethered them and took to our feet to climb the loose slabs of rock and the snow-covered stretches of the peaks and to peer over the top of the crags on to the ledges where live the rocky mountain goats.

As a piece of classical northern beauty in the autumn sunshine, you will find its equal only elsewhere in British Columbia. The Government of that Province are greatly to be congratulated on their determination to retain for ever so large a stretch of fairylike natural wilderness. Let us pray that it will not be threatened again by economic man, and that it will rest superb, remote and undisturbed.

\title{
THE FUTURE OF REINDEER IN SCOTLAND
}

\section{By M. N. P. UTsI}

\section{Technical Adviser, Reindeer Council of the United Kingdom}

When the current reindeer experiment in Scotland is discussed I am sometimes asked : "Why try to introduce, or reintroduce, reindeer when there are probably as many red deer as the ground can carry and certainly more than the black-faced-sheep farmers want?"

On my first visit to Scotland, nearly ten years ago, I was very proud to catch a glimpse of red deer grazing in the Spey valley. "The monarch of the glen" on a crag is a stately sight, or a herd galloping with heads held high. After the rut, on the other hand, stags become " lean as herons ", to quote David Stephen.

Red decr are still numerous in some deer forests and landowners formerly had good reason to welcome them for the sake of the income from stalking tenants ; but nowadays such lettings are often unobtainable. There are also afforested and other extensive regions where red deer are not wanted at all and are excluded by miles of $6 \mathrm{ft}$. fencing. Because red decr require the protection of woods in winter, and deer forests are often almost treeless to-day, the red deer come so close to the villages that they may become a menace to agricultural land and much resented by smallholders. Highland grazing and farming needs every piece of land it can use to produce becf, mutton, milk, wool and leather, corn, potatoes, turnips and other crops.

Yet Scotland without red decr would seem empty to everyone, and I believe there would be little complaint from smallholders if they stood to gain something, sport or profit, from invading 
red decr. Sentiment apart, venison represents a food reserve which rivals, in my opinion, the best beef if the animal is stalked at the right time of year and the meat is properly handled. Fraser Darling has stated in the Observer (22nd July, 1956) that " properly managed both on the ground and in marketing it could contribute a thousand tons of high-quality meat to the nation's larder each year". I am sure that the proposed close scason for red deer would result in venison deserving, and obtaining, better recognition as a first-class type of food.

To judge from observation and scattered references in the literature, red deer are almost omnivorous, though according to Kenneth Whitehead grass heads the list. Lichens are sometimes mentioned, but the late Duncan A. MeLeod, of Coylum Bridge, with experience of Ardverikic and other deer forests behind him, declared that he had only found red deer nibbling them once in a very hard winter, when they were trapped on a height by snow and were starving. It is only necessary to examine Scottish hill slopes covered by short heather to convince oneself that the various ground, rock and tree lichens eaten by reindeer play an insignificant part in the diet of red deer, roc deer, sheep, or other indigenous animals. In places the lichens form a carpet several inches deep. It was this discovery of untouched lichens that gave rise to the reindeer experiment now proceeding in Scotland.

In northern Scandinavia there are over 600,000 domesticated reindeer and in the northern U.S.S.R. reputedly two million, valued for their meat, skins, milk and hair, and for transport. These obvious benefits have led to the Alaskan, Canadian, South Georgian and other modern imports of reindeer. Usually described as an aretic animal, the reindeer is widely found in the sub-arctic and in zones regarded as "temperate"; the Scandinavian range is $60^{\circ}-72^{\circ}$ lat. $N$., the Alaskan $55^{\circ}-72^{\circ}$ lat. $N$., and in Manchuria they begin at $52^{\circ}$ lat. $N$.

There were many reindeer in Scotland in prehistoric times, and they were mentioned as being hunted, with red decr, in Caithness by the Jarls of Orkney in the thirteenth century. Why these wild reindecr died out while the red deer remained is unknown, but one can make suggestions. Reindecr meat was probably more popular; also the pre-firearm techniques of the chase were not equal to climinating the generally flecter red deer. The importance of forests has sometimes been emphasized in this connection. No doubt when woods were burned to clear out wolves, the reindeer became still more vulnerable.

Why should reindecr be "foreed" to live in Scotland when they had once died out, whatever the causes? In reply it may 
be said, first, that Britain imported in 1951 and 1952 about 382 tons of reindecr meat from Sweden, all of which sold in London and clsewhere at prices averaging $4 s_{0}-5 s$, a pound. That the imports dwindled after meat rationing ended was attributed to the high price, which could not be lowered in view of the good price level maintained by the steady home demand in Scandinavia.

Good meat can more casily be obtained at the time it is wanted, and be carefully handled, when it comes from a tame or at least half-tame animal. Reindeer owners, whatever their language or origin, eat mainly or only reindecr meat. Indecd, their farming neighbours often buy reindeer meat, in spite of owning meat-producing animals themselves. In the cities and towns of Scandinavia it is rated a délicatesse, and an article in the Nerv Yorli Times (8th July, 1956) remarks that the meat "tastes a good deal like bee (when available in New York it costs about $\$ 2.25$ a pound); the tender tongue is a delicacy in Europe".

Among many other uses. of reindecr products it should be noted especially that the hide tans to a fine chamois-like surface suitable for ladies' gloves and handbags.

The leader of the experimental herd has now been in Scotland four and a half ycars and weighed 17 stone $4 \mathrm{lb}$. on 3rd September, 1956 (Avicmorc railway station). After setbacks on, unsuitable land the herd has been increasing since May, 1955, through calves bred and born in the Cairngorms and now numbers sixteen head.

Most domesticated reindecr in northern latitudes, though not all; migrate in winter to land where woods provide shelter; their herders also try to get them away from high lands where they are more cxposed to wolves and other wild animals. But in the Cairngorms the experimental reindecr have, when not fenecd in, tended to move up to lichen-rich tops in winter, however hard it blows.

When considering the future of reindecr in Scotland, it may be admitted that there is some overlap between the pasture of reindecr, red decr and sheep. But as there arc areas in Scotland which are scarcely grazed by red deer or sheep yet offer good reindecr pasture, this slight overlap would not justify the exclusion of reindecr.

The reindeer chiefly eat lichens which other animals hardly touch ; an important natural resource is therefore made productive through their agency.

The reindecr may be needed some dny. 